\title{
Initial copper stress strengthens the resistance of soil microorganisms to a subsequent copper stress
}

Jing $\mathrm{Li}^{1,2}$, Yuan-Ming Zheng ${ }^{1}$, Yu-Rong Liu ${ }^{1}$, Yi-Bing $\mathrm{Ma}^{3}$, Hang-Wei Hu${ }^{1,4}$, Ji Zheng $\mathrm{He}^{1,4, *}$

${ }^{1}$ State Key Laboratory of Urban and Regional Ecology, Research Center for Eco-Environmental Sciences, Chinese Academy of Sciences, Beijing 100085, China

${ }^{2}$ University of Chinese Academy of Sciences, Beijing 100049, China

${ }^{3}$ Key Laboratory of Plant Nutrition and Nutrient Cycling, Ministry of Agriculture, Institute of Agricultural Resources and Regional Planning, Chinese Academy of Agricultural Sciences, Beijing 100081, China

${ }^{4}$ Melbourne School of Land and Environment, the University of Melbourne, Parkville 3052, Victoria, Australia

Corresponding author: Ji-Zheng He, Email: izhe@ @rcees.ac.cn or jizheng.he@unimelb.edu.au, Phone: +861062849788

Running title: Initial stress increases resistance of soil microorganisms to subsequent stress

Type of contribution: Regular papers

Date of preparation: 16 December 2013

Number of text pages: 14

Number of figures: 6

Number of table: 1 


\section{Abstract}

To improve the prediction of essential ecosystem functioning under future environmental disturbances, it is of significance to identify responses of soil microorganisms to environmental stress. In this study, we collected polluted soil samples from field plots with eight copper levels ranging from 0 to $3200 \mathrm{mg}$ $\mathrm{Cu} \mathrm{kg}{ }^{-1}$ soil. Then the soils with 0 and $3200 \mathrm{mg} \mathrm{Cu} \mathrm{kg}^{-1}$ were selected to construct a microcosm experiment. Four treatments were set up including $\mathrm{Cu} 0-\mathrm{C}$ and $\mathrm{Cu} 3200-\mathrm{C}$ without further $\mathrm{Cu}$ addition, and $\mathrm{Cu} 0-\mathrm{A}$ and $\mathrm{Cu} 3200-\mathrm{A}$ with addition of $57.5 \mathrm{mg} \mathrm{Cu} \mathrm{kg}{ }^{-1}$ soil. We measured substrate induced respiration (SIR) and potential nitrification rate (PNR). Furthermore, the abundance of bacterial, archaeal 16S rRNA genes, AOB and AOA amoA genes were determined through qPCR. The soil microbial communities were investigated by T-RFLP. For the field samples, The SIR and PNR as well as the abundance of soil microorganisms varied significantly between eight copper levels. Soil microbial communities highly differed between the low and high copper stress. In the microcosm experiment, the PNR and SIR both recovered while the abundance of soil microorganisms varied irregularly during the 90-day incubation. The differences of microbial communities measured by pairwise Bray-Curtis dissimilarities between $\mathrm{Cu} 0-\mathrm{A}$ and $\mathrm{Cu} 0-\mathrm{C}$ on day 0 were significantly higher after subsequent stress than before. However, the differences of microbial communities between Cu3200-A and $\mathrm{Cu} 3200-\mathrm{C}$ on day 0 changed little between after subsequent stress and before. Therefore, initial copper stress could increase the resistance of soil microorganisms to subsequent copper stress.

Key words : initial copper stress; subsequent copper stress; resistance; soil microbial community composition; Bray-Curtis dissimilarity

\section{Introduction}

Stress is a physiological or functional effect which has particular biological meaning [1]. Heavy metal pollution is one type of common chemical stresses and ubiquitous in the soil ecosystems. Copper is one of the widely investigated heavy metals in agricultural soils. It is a necessary trace element which acts as a prosthetic group participating in varieties of metabolic pathways in prokaryote cell. However, excessive copper is toxic to soil microorganisms by oxidizing protein, lipid and DNA, and thereby results in cell death [2]. The major pathways that copper entered into soil are copper-based pesticides 
and copper contaminated manure [3]. It has been demonstrated that long-term use of copper-based fungicides can result in the accumulation of copper in soils [4, 5]. This caused changes of soil biochemical properties and had adverse effects on soil enzymes and organisms (e.g. earthworms, microorganisms). Moreover, copper pollution exerts a potential risk to the long-term fertility of soils and the basic functions of soil ecosystem $[4,5]$.

Studies have demonstrated that copper pollution could disturb the soil microbial community, leading to a decrease of microbial biomass and a shift in the microbial community structure $[6,7]$. Microorganisms are the key players driving soil ecosystem services and functioning. They have essential roles in maintaining the global nitrogen biogeochemical cycles, such as the processes of nitrogen fixation, nitrification and denitrification. Ammonia oxidation is the first and rate-limiting step of nitrification which converts ammonium to nitrate via nitrite, and contributes significantly to the global emissions of greenhouse gas $\mathrm{N}_{2} \mathrm{O}$ [8]. This pivotal process was presumed to be performed by ammonia-oxidizing bacteria (AOB) for over a century [9], and recently expanded to the newly-discovered ammonia-oxidizing archaea (AOA) [10]. AOB have been frequently used as an indicator for various soil perturbations, for instance, herbicides [11] and wastewater irrigation [12]. Recent findings suggested that AOA could also act as an indicator for soil enduring stresses, such as agricultural practices [13]. Therefore, it is fundamental to explore the response of soil ammonia oxidizers to heavy metal stress.

Conceptually, ecological stability is closely linked to the characteristics of stress [1]. Intensities, frequencies and duration of stresses can profoundly influence an ecosystem and may force an ecosystem to exceed a threshold [14]. There are two possible responses that ecological systems are subject to stresses: one is that ecological systems might be partially or totally altered to reach a new stable state, the other is that ecological systems might be unaffected and maintain the current stable state [15]. Stability could be quantified by measuring resistance, a metric for indicating responses. Resistance could be defined as a degree to which a system withstands change in face of stress [15].

The impacts of copper stress on the stability of soil microorganisms have been intensively investigated, but contrasting results were reported concerning both negative and positive effects. Generally, copper stress could change structures of archaeal, bacterial and fungal communities [16]. Previous studies analyzing the bacterial community compositions found that copper had positive effects on Actinobacteria [17] and negative effects on Acidobacteria [16]. In addition, it is important to 
understand how repeated stresses influence microbial community. The influence of initial stress on resistance and resilience of soil microbial community to a subsequent stress was less studied and is still being debated [18]. Compared with the uncontaminated soil, soil microorganisms in the heavy-metal contaminated soil were more affected by a subsequent heat or salt stress due to the less energy of stressed system to cope with additional stress [19]. However, ammonia oxidizers in long-term zinc contaminated soil were less sensitive to a secondary zinc stress than that in the uncontaminated soil because of the zinc tolerance of long-term zinc contaminated soil [20]. The objective of this study was to quantitatively explore whether initial copper stress could improve the stability of soil microorganisms to the secondary copper stress.

We collected copper contaminated soil samples from field plots with different copper contamination levels (0-3200 $\left.\mathrm{mg} \mathrm{kg}^{-1}\right)$. The objective of the field experiment was to explore how soil microorganisms responded to different intensities of copper stress. In the following microcosm experiment, we used field soil samples to explore the resistance of soil microorganisms to the subsequent copper addition. We hypothesized that soil microorganisms were more resistant to the subsequent copper stress after exposure to the initial copper stress.

\section{Materials and methods}

\section{Field description and soil sampling}

The field experiment was established in Dezhou ( $\left.37^{\circ} 20^{\prime} \mathrm{N}, 116^{\circ} 38^{\prime} \mathrm{E}\right)$, Shandong Province, China, in June 2007. The site has a temperate continental climate with a mean annual temperature of $12.9^{\circ} \mathrm{C}$ and mean annual rainfall of $547.5 \mathrm{~mm}$. The soil is classified as fluvo-aquic soil according to the Chinese soil taxonomy with $\mathrm{pH}$ value of around 7.9 and cation exchange capacity (CEC) of $8.33 \mathrm{cmol}^{+} \mathrm{kg}^{-1}$ soil. The soil contains $64 \%$ sand, $18 \%$ silt, and $18 \%$ clay. Briefly, the surface soil was mixed with copper chloride powder, and then supplied to the soil surface layers to form a copper pollution gradient in the experimental plots. There were eight copper level treatments with four replicated plots $\left(2 \times 2 \mathrm{~m}^{2}\right)$ for each treatment. The added copper levels ( $\mathrm{mg} \mathrm{kg}^{-1}$ soil) were 0 (Cu0), 50 (Cu50), $100(\mathrm{Cu} 100), 200$ (Cu200), 400 (Cu400), 800 (Cu800), 1600 (Cu1600), and 3200 (Cu3200). The plots were planted with corn/wheat rotation under conventional field management practices in subsequent years. Soil samples were collected from the top $10 \mathrm{~cm}$ by mixing five soil cores for each plot in July 2011. Soil samples 
were stored at $4^{\circ} \mathrm{C}$ for physicochemical property analyses and $-80^{\circ} \mathrm{C}$ for DNA extraction.

\section{Microcosm incubation}

In order to ensure a significant divergence of soil microbial community between the initial stressed and non-stressed treatments, $\mathrm{Cu} 0$ and $\mathrm{Cu} 3200$ samples from the field were chosen for a short-term microcosm incubation to explore the response of soil microbial community to subsequent copper stress. This incubation had four treatments: $\mathrm{Cu} 0$ and $\mathrm{Cu} 3200$ soil samples with $(\mathrm{Cu} 0-\mathrm{A}$ and $\mathrm{Cu} 3200-\mathrm{A})$ or without (Cu0-C and Cu3200-C) addition of $57.5 \mathrm{mg} \mathrm{Cu} \mathrm{kg}^{-1}$ soil. According to the environmental quality standard for soils in China, this concentration was below the secondary standard level whereas it can also induce stress effect. The copper concentrations in $\mathrm{Cu} 0-\mathrm{C}$ and $\mathrm{Cu} 3200-\mathrm{C}$ were 8.2 and 3341.0 $\mathrm{mg} \mathrm{Cu} \mathrm{kg}{ }^{-1}$ soil, respectively; while those in $\mathrm{Cu} 0-\mathrm{A}$ and $\mathrm{Cu} 3200-\mathrm{A}$ were 65.7 and $3398.5 \mathrm{mg} \mathrm{Cu} \mathrm{kg}^{-1}$ soil (Table 1), respectively. There were 18 vials ( 3 replicates $\times 6$ time points) for each treatment. Each vial with a loose cover to allow air exchange was incubated at a constant temperature of $25^{\circ} \mathrm{C}$ for 90 days. Soil moisture was replenished regularly to keep a constant content. Soil samples were destructively collected at days $0,3,7,21,42$ and 90 .

\section{Soils chemical analyses}

Soil $\mathrm{pH}$ was determined with a soil to water ratio of 1:2.5 using a $\mathrm{pH}$ meter. Soil moisture was measured after oven drying at $105^{\circ} \mathrm{C}$ for eight hours. Soil organic carbon was determined using the $\mathrm{K}_{2} \mathrm{Cr}_{2} \mathrm{O}_{7}$ oxidation-reduction colorimetric method. Soil total $\mathrm{Cu}$ was digested with aqua regia and determined by ICP-OES (OPTIMA 2000 DV, PerkinElmer, USA).

\section{Potential nitrification rate $(\mathbf{P N R})$}

Soil potential nitrification rate was determined as described previously [21, 22]. Briefly, $5.0 \mathrm{~g}$ of fresh soil was added into a $50 \mathrm{ml}$ falcon tube containing $20 \mathrm{ml}$ of phosphate buffer solution (PBS) $\left(\mathrm{g} \mathrm{L}^{-1}\right.$ : $\left.\mathrm{NaCl}, 8.0 ; \mathrm{KCl}, 0.2 ; \mathrm{Na}_{2} \mathrm{HPO}_{4}, 2.2 ; \mathrm{KH}_{2} \mathrm{PO}_{4}, 0.24\right)$ with $1 \mathrm{mM}\left(\mathrm{NH}_{4}\right)_{2} \mathrm{SO}_{4}$ and $50 \mathrm{mM}\left(\mathrm{KClO}_{3}\right)$. After 24 hours' incubation in a rotary shaker at $25^{\circ} \mathrm{C}, 5 \mathrm{ml}$ of $2 \mathrm{M} \mathrm{KCl}$ was added to the tube for extraction of $\mathrm{NO}_{2}^{-}-\mathrm{N}$. The $\mathrm{NO}_{2}^{-}-\mathrm{N}$ concentration was determined by reacting with sulfanilic acid $\left(\mathrm{C}_{6} \mathrm{H}_{7} \mathrm{NSO}_{3}\right)$ and 1-Naphthylamine $\left(\mathrm{C}_{10} \mathrm{H}_{9} \mathrm{~N}\right)$ and measuring at $530 \mathrm{~nm}$ using a spectroscopy. 


\section{Substrate induced respiration (SIR)}

$5.0 \mathrm{~g}$ soil samples were pre-incubated in the $150 \mathrm{ml}$ glass flasks under anaerobic conditions to keep constant moisture content at $25^{\circ} \mathrm{C}$ for 3 days before the measurement. The substrate was a mixture of

$\mathrm{C}_{6} \mathrm{H}_{12} \mathrm{O}_{6},\left(\mathrm{NH}_{4}\right)_{2} \mathrm{SO}_{4}$ and $\mathrm{KH}_{2} \mathrm{PO}_{4}$ which were thoroughly ground and mixed in a mortar and the ratio of these three reagents was $80: 13: 2$. Then the substrate was homogeneously added into the soil with a ratio of $1 \%$ (i.e. $1 \mathrm{~g}$ of substrate added into $100 \mathrm{~g}$ of dry soil). $\mathrm{CO}_{2}$ was collected in air bags every one hour after the substrate addition. A minimum of 3 hourly measurements should be ensured to calculate the average values [23]. The concentrations of $\mathrm{CO}_{2}$ were determined using a gas chromatograph (Agilent 7890A GC System).

\section{DNA Extraction and quantitative PCR (qPCR)}

DNA was extracted from triplicate fresh soil samples $(0.5 \mathrm{~g})$ using a MoBio UltraClean ${ }^{\mathrm{TM}}$ soil DNA isolation kit (MO BIO Laboratories, San Diego, CA, USA) according to the manufacturer's protocol.

Abundance of bacterial 16S rRNA gene was quantified using the primer pairs BACT1369F and PROK1492R as well as the probe TM1389F [24, 25]. Each reaction was performed in a $25 \mu 1$ volume containing $12.5 \mu 1$ Premix Ex Taq, $0.25 \mu 1$ of each primer, $0.5 \mu 1$ of the probe and $1 \mu 1$ of 5-fold-diluted DNA template $(1-10 \mathrm{ng})$. Amplification conditions were as follows: $95^{\circ} \mathrm{C}$ for $10 \mathrm{~s}, 35$ cycles of $15 \mathrm{~s}$ at $95^{\circ} \mathrm{C}$ and $1 \mathrm{~min}$ at $56^{\circ} \mathrm{C}$.

Abundance of archaeal 16S rRNA gene was quantified using the primer pairs A364aF and A934bR [26]. Each reaction was performed in a $25 \mu 1$ volume containing $12.5 \mu 1$ SYBR Premix Ex Taq, $0.5 \mu 1$ of each primer and $2 \mu 1$ of 5-fold diluted DNA template (1-10 ng). Amplification conditions were as follows: $94^{\circ} \mathrm{C}$ for $1 \mathrm{~min}, 40$ cycles of $20 \mathrm{~s}$ at $94^{\circ} \mathrm{C}, 30 \mathrm{~s}$ at $59^{\circ} \mathrm{C}$, and $30 \mathrm{~s}$ at $72^{\circ} \mathrm{C}$, followed by plate reads at $83^{\circ} \mathrm{C}$.

Abundance of the AOA amoA gene was determined using the primer pairs Arch-amoAF and Arch-amoAR [27,28]. Each reaction was performed in a $25 \mu$ l volume containing $12.5 \mu 1$ SYBR Premix Ex Taq (TaKaRa Biotechnology, Dalian, China), $0.5 \mu 1$ of each primer $(10 \mu \mathrm{M})$ and $2 \mu 1$ of 5-fold diluted DNA template (1-10 ng). Thermocycling conditions were as follows: $95^{\circ} \mathrm{C}$ for $3 \mathrm{~min}, 35$ cycles of $10 \mathrm{~s}$ at $95^{\circ} \mathrm{C}, 30 \mathrm{~s}$ at $55^{\circ} \mathrm{C}$, and $1 \mathrm{~min}$ at $72^{\circ} \mathrm{C}$, and followed by plate reads at $83^{\circ} \mathrm{C}$. The AOB 
amoA gene was quantified using the primer pairs amoA1F and amoA2R [28,29] with the same reaction conditions as the archaeal $a m o A$ gene except a degeneration time of 1 min and plate reads at $85{ }^{\circ} \mathrm{C}$. All the qPCR analysis was conducted on an iCycler iQ 5 thermocycler (Bio-Rad Laboratories, Hercules, CA, USA). Melting curve analysis was performed at the end of each qPCR run to check the specificity of the amplification products.

Standard curves of archaeal 16S rRNA gene, AOB and AOA amoA genes were developed using the same primers as qPCR while using primers BACT27F/PROK1492R for amplifying bacterial 16S rRNA gene. Then the PCR products were purified and cloned into the pGEM-T Easy Vector (Promega). Plasmids with the target genes were extracted from the positive clones for sequencing and the concentrations were determined on a Nanodrop® ND-1000 UV-Vis Spectrophotometer (NanoDrop Technologies, Wilmington, DE). The plasmid concentrations were used to calculate standard copy numbers. Ten-fold serial dilutions of the plasmids were generated to make the standard curves.

\section{T-RFLP analysis of the microbial communities}

The PCR amplification of bacterial 16S rRNA gene for T-RFLP analysis was carried out using the primer pairs FAM-labeled BACT27F and PROK1492R primers. The archaeal 16S rRNA gene was amplified using the primers A364aF and FAM-labeled A934bR. AOA T-RFLP profiles were obtained from the FAM-labeled CrenamoA23f and CrenamoA616r primers. For AOB analysis, the bacterial amoA partial gene fragment was PCR-amplified using the labeled primers amoA-1F and amoA-2R. The FAM-labeled PCR products were purified using a Wizard SV Gel and PCR Clean-up system (Promega, San Luis Obispo, CA, USA). The restriction enzyme (HhaI) was used for digestions of the bacterial and archaeal 16S rRNA genes as well as AOA amoA gene. AOB PCR products were restricted with MspI. $1 \mu 1$ or $2 \mu 1$ of the purified products was mixed with deionized formamide and the internal standard of GeneScan-1200 ROX (Applied Biosystems, Foster City, CA). Fragment size analysis was carried out with a 3730xl genetic analyzer (Applied Biosystems, Warrington, UK). All TRFs (terminal restriction fragments) with fluorescence units $<50$ and peaks with heights less than $1 \%$ of the total peak height were excluded from further analysis. Fragments above $10 \%$ relative abundance were regarded as dominant TRFs [30]. 


\section{Cloning and sequencing}

In order to assign phylogenetic affiliation to specific TRFs, four clone libraries were constructed for bacterial and archaeal 16S rRNA genes, AOA and AOB amoA genes. The PCR products were purified and ligated into the pGEM-T Easy Vector (Promega). Ligation mix was then transformed into Escherichia coli JM109 competent cells following the manufacturer's instructions. After re-amplification with the vector-specific primers T7 and SP6, 200 positive clones for bacteria, 100 for archaea, 120 for $\mathrm{AOB}$ and 115 for AOA were randomly selected from each clone library for sequencing. The obtained sequences were aligned in the MEGA [31] and processed in QIIME 1.7.0 [32]. The partial bacterial and archaeal 16SrRNA gene sequences have been deposited to the NCBI database under the accession number KJ081610-KJ081644 and KJ081673-KJ081690, respectively, and the partial ammonia oxidizing bacterial and archaeal amoA gene sequences under accession number KJ081645-KJ081672.

\section{Statistics}

Spearman's correlations, paired-samples T test and one-way ANOVA analyses were conducted using SPSS version 19.0 (IBM Co., Armonk, New York), and $p<0.05$ was considered to be statistically significant. The principle coordinates analysis (PCoA) was based on the Bray-Curtis dissimilarity using QIIME 1.7.0 [32]. The significance of the community difference was examined by the permutation multivariate analysis of variance (PerMANOVA). The differences of microbial community were measured by pairwise Bray-Curtis dissimilarities between $\mathrm{Cu} 0-\mathrm{A}$ and $\mathrm{Cu} 0-\mathrm{C}$ on day 0 as well as Cu3200-A and Cu3200-C on day 0. The variations of the differences were the metric for community resistance [33, 34]. Then we compared the differences of Bray-Curtis dissimilarities using Welch's $t$-test.

\section{RESULTS}

Effects of initial copper stress on activities, abundance and compositions of soil microorganisms

The potential nitrification rates (PNR) of the soil samples (1.22-2.41 $\mathrm{mg} \mathrm{NO}_{2}^{-}-\mathrm{N} \mathrm{kg}^{-1}$ dry soil h${ }^{-1}$ ) did 
not decrease with increasing $\mathrm{Cu}$ concentrations, and the PNR at $\mathrm{Cu} 50$ was the lowest accounted for about $50 \%$ of that at the Cu3200 treatment (Fig. 1a). Highest PNR was recorded at Cu3200. In contrast, SIR declined consistently with increasing $\mathrm{Cu}$ concentrations except at the Cu3200 treatment (Fig. 1b).

Bacterial 16S rRNA gene copy numbers ranged from $2.83 \times 10^{9}$ to $4.40 \times 10^{10}$ copies $\mathrm{g}^{-1}$ soil and significantly decreased along the gradient of $\mathrm{Cu}$ concentrations (Fig. 2a). Archaeal 16S rRNA gene copy numbers $\left(6.00 \times 10^{6}\right.$ to $2.79 \times 10^{7}$ copies $\mathrm{g}^{-1}$ soil $)$ also significantly decreased with increasing $\mathrm{Cu}$ concentrations since $\mathrm{Cu} 400$ (Fig. 2b). In addition, AOB amoA gene copy numbers were highly variable among the eight treatments ranging from $9.59 \times 10^{7}$ to $3.28 \times 10^{8}$ copies $\mathrm{g}^{-1}$ soil, but no obvious trend along the $\mathrm{Cu}$ gradient was observed (Fig. 2c). AOA amoA gene copy numbers were significantly higher in the $\mathrm{Cu} 0$ and $\mathrm{Cu} 50$ treatments than that in the other treatments (Fig. 2d).

T-RFLP analysis of bacterial and archaeal 16S rRNA gene with the HhaI enzyme produced nine and five distinct terminal restriction fragments (TRFs) across the eight treatments, respectively (Fig. 3a and 3c). The most dominant TRFs of bacterial 16S rRNA gene were TRFs-139, -161, -163 and -169 . For archareal 16S rRNA gene, the dominant TRFs were TRFs-139, -169 and -516. The percentage of TRF-69 in Cu3200 for bacteria was 5.0\% while for archaea was $10.5 \%$, highest among all the soil samples. The PCoA results revealed that the bacterial and archaeal communities between low and high copper stress significantly separated (Fig. 3b and 3d). Clone libraries were constructed containing all the TRFs for bacterial and archaeal 16S rRNA genes. Most of the bacterial 16S rRNA gene sequences were affiliated to five phyla which were Proteobacteria, Bacteroidetes, Planctomycetes, Actinobacteria and Acidobacteria. Among the five phyla, Proteobacteria phylum was dominant, furthermore, Betaproteobacteria were the dominant group. $83 \%$ of the archaeal 16S rRNA gene sequences belonged to the Nitrososphaerales, the other $17 \%$ sequences belonged to Thermoplasmales.

A total of five distinct AOB TRFs were obtained from the soil samples with the MspI enzyme, where TRFs-37, -215 and -237 were the most dominant ones (Fig. 3e). Interestingly, TRF-245 was absent in soils with high copper concentrations including Cu800, Cu1600 and Cu3200. Additionally, the number of TRFs was less in $\mathrm{Cu} 800, \mathrm{Cu} 1600$ and $\mathrm{Cu} 3200$. Nine TRFs were produced for AOA with the HhaI enzyme (Fig. 3g). TRF-539 was not detected in Cu800, Cu1600 and Cu3200. The percentage of TRF-581 in Cu3200 was $29.6 \%$ which was the highest among all the soil samples. In contrast, the ratio of TFR-147 in $\mathrm{Cu} 3200$ was $8.15 \%$ which was the lowest. The PCoA results revealed that the AOB and AOA communities were well separated between the low and high copper stress (Fig. $3 \mathrm{f}$ and $3 \mathrm{~h}$ ). 
Clone libraries were constructed containing all the TRFs for AOB and AOA amoA genes. All the AOB clone sequences were belonging to the Nitrosospira and Nitrosomonas genera. But the Nitrosospira was notably predominant. Most of the AOA sequences were affiliated to the Nitrososphaera cluster. Only a small part of the sequences were affiliated to Nitrosopumilus cluster.

\section{Effects of subsequent copper stress on activities, abundance and compositions of soil microorganisms}

The function, abundance of soil microorganisms as well as the compositions of soil microbial communities highly differed between $\mathrm{Cu} 0$ and $\mathrm{Cu} 3200$. Therefore, $\mathrm{Cu} 0$ and $\mathrm{Cu} 3200$ were selected to set up Cu0-C, Cu0-A, Cu3200-C and Cu3200-A treatments. The PNR of all treatments significantly decreased on day 21. The PNR of Cu0-A and Cu3200-A were $23 \%$ and $24 \%$ of that on day 0 as well as Cu0-C and $\mathrm{Cu} 3200-\mathrm{C}$ with $67 \%$ and $56 \%$ of the PNR on day 0 (Fig. 4a). The PNR of Cu0-A and Cu3200-A decreased more quickly than that of Cu0-C and Cu3200-C. Although significant recovery of the PNR occurred in soils except Cu3200-A on day 90, the PNR in all treatments on day 90 were significantly lower than that on day 0. The SIR of $\mathrm{Cu} 0-\mathrm{C}$ and $\mathrm{Cu} 0-\mathrm{A}$ ranged from 1.82 to $11.44 \mu 1 \mathrm{CO}_{2}$ $\mathrm{g}^{-1}$ dry soil $\mathrm{h}^{-1}$ while the SIR of Cu3200-C and Cu3200-A ranged from 0.49 to $4.53 \mu \mathrm{CO}_{2} \mathrm{~g}^{-1}$ dry soil $\mathrm{h}^{-1}$. The SIR of $\mathrm{Cu} 0-\mathrm{C}$ and $\mathrm{Cu} 0-\mathrm{A}$ was strongly higher than that of $\mathrm{Cu} 3200-\mathrm{C}$ and $\mathrm{Cu} 3200-\mathrm{A}$. The SIR in all soils reached highest on day 7 (Fig. 4b). Recovery tendencies were also observed that the SIR in all treatments on day 90 was significantly higher than that on day 0.

Bacterial 16S rRNA gene copy numbers of all treatments varied from $5.51 \times 10^{8}$ to $5.64 \times 10^{9}$ copies $\mathrm{g}^{-1}$ soil (Fig. 5a). Archaeal 16S rRNA gene copy numbers of all treatments varied from $6.33 \times 10^{6}$ to $1.20 \times 10^{8}$ copies $\mathrm{g}^{-1}$ soil (Fig. 5b). There were no obvious differences between all treatments. Abundance of bacteria and archaea were not significantly different between day 90 and day 0 .

AOB amoA gene copy numbers varied from $7.88 \times 10^{5}$ to $1.89 \times 10^{7}$ copies $\mathrm{g}^{-1}$ soil (Fig. $5 \mathrm{c}$ ). AOA

amoA gene copy numbers varied from $1.36 \times 10^{6}$ to $1.15 \times 10^{7}$ copies $\mathrm{g}^{-1}$ soil (Fig. $5 \mathrm{~d}$ ). Similar with bacteria and archaea, unclear differences were observed between all treatments. Abundance of AOB and AOA were also not significantly different between day 90 and day 0 .

For the bacterial community, the relative abundance of TRFs in Cu0-A and Cu3200-A varied after the subsequent copper stress and the new TRF-58 was found on day 21, 42 and 90 (Fig. 6a). For the archaeal community, the relative abundance of TRF-62 in Cu0-A as well as TRF-69 in Cu3200-A 
strongly increased during the incubation period (Fig. 6c). For AOA community, the relative abundance of TRF-615 and TRF-527 decreased to none in Cu3200-A (Fig. 6g). Only in AOB community, the relative abundance of TRFs in $\mathrm{Cu} 0-\mathrm{A}$ and $\mathrm{Cu} 3200-\mathrm{A}$ changed little after the subsequent copper stress (Fig. 6e).

The Bray-Curtis dissimilarity based on AOA community of Cu0-A on day 3 was 0.17 significantly higher than 0.06 on day $0(p<0.05)$. However, the Bray-Curtis dissimilarity based on AOA community of Cu3200-A on day 3 was 0.05 which showed no difference with 0.03 on day 0 ( $p>0.05$ ) (Fig. 6h). Similarly, both the Bray-Curtis dissimilarities based on AOB community and archaeal community of $\mathrm{Cu} 0$-A on day 3 were strongly higher than that on day $0(p<0.05)$. Moreover, the Bray-Curtis dissimilarities of Cu3200-A also varied little between day 3 and day 0 (Fig. $6 \mathrm{f}$ and $6 \mathrm{~d}$ ). But in terms of bacterial community, the Bray-Curtis dissimilarities of $\mathrm{Cu} 0-\mathrm{A}$ and $\mathrm{Cu} 3200-\mathrm{A}$ on day 3 were both strongly higher than that on day $0(p<0.05)$ (Fig. 6b). In addition, the Bray-Curtis dissimilarities based on the four communities of $\mathrm{Cu} 0-\mathrm{A}$ and $\mathrm{Cu} 3200-\mathrm{A}$ on day 90 were significantly higher than those on day $0(p<0.05)$.

\section{Discussion}

\section{Response of soil microorganisms to initial stress}

SIR which was the generic soil microbial function was significantly affected by initial copper stress. Similarly to SIR, the abundance of bacteria and archaea both responded sensitively to initial copper stress. Long-term copper exposure exerted strong influences on the bacterial community structure [35, 36]. Our PCoA results further supported that the prokaryotes responded intensively to high copper stress. From the microbial function to the abundance and then the microbial composition, our results agreed with previous observational work which suggested most soil-inhabited microbes are sensitive to stresses [37].

PNR as a specific functional indicator of soil ammonia oxidizers did not decrease with the elevated copper concentrations, which might suggest that PNR was scarcely affected by the copper stress in the long term. The abundance of AOA significantly decreased after Cu50. Nevertheless, unclear variation tendency of AOB based on the abundance was observed but significant difference was observed between $\mathrm{Cu} 0$ and $\mathrm{Cu} 3200$. The AOA and AOB community structured divergently between 
low and high copper according to the PCoA results. It could be considered that the specific functional microorganisms were also strongly disturbed by the copper stress. The functional microorganisms gradually adapted to the stressed environment to maintain the function through the shifts in community compositions.

Our results provided direct evidence that the generic function (SIR) was more sensitive to the five-year copper stress than specific function (PNR). It demonstrated that general functions such as microbial respiration and broad metabolic function were not necessarily more resilient than some specialized functions in these stressed ecosystems [36]. Microbial community compositions, however, more sensitively respond to stresses than functions.

\section{Responses of soil microorganisms to a subsequent stress}

For ammonia oxidizing microorganisms, the differences of microbial communities between $\mathrm{Cu} 0-\mathrm{A}$ and $\mathrm{Cu} 0-\mathrm{C}$ on day 0 were significant higher after subsequent copper stress than before. However, the differences of microbial communities between Cu3200-A and Cu3200-C on day 0 varied little between before and after the subsequent copper stress. This result demonstrated that the initial copper stress increased the resistance of soil ammonia oxidizers to subsequent copper stress. There was the same variation tendency for the archaeal community which might be explained that AOA was the dominant group in the archaeal community in this soil. This phenomenon might be explained that microbial communities in the long-term field contaminated soil have already adapted to the toxic environment, therefore microbial communities were more resistant to subsequent stress [38, 39]. The adaption process of microorganisms to heavy metals might be emphasized by genetic or physiological changes of microorganisms (mutations or horizontal gene transfer) [40, 41]. Moreover, at a community level, metal-sensitive species were substituted by metal-tolerant or adapted species [42, 43]. Furthermore, for prokaryotes, the differences of microbial communities between $\mathrm{Cu} 0-\mathrm{A}$ and $\mathrm{Cu} 0-\mathrm{C}$ on day 90 were strongly higher than that on day 0. The differences of microbial communities between Cu3200-A and Cu3200-C showed the same variations. This indicated that both the initial stressed and non-stressed microbial communities changed irreversibly and constructed new communities. The microbial communities structured divergently and could not return to the initial status during the incubation period might be explained that the time was too short for them to recover. Although the community composition for prokaryotes altered drastically responded to the subsequent copper stress, the 
abundance of bacteria and archaea varied unclearly. SIR increased rapidly after the subsequent copper stress and then decreased. But SIR on day 90 was significantly higher than that on day 0 which meant that the function had been recovered. Terms for ammonia oxidizing microorganisms, PNR rapidly decreased after adding freshly copper and then showed a recovery tendency indicating that the changed $\mathrm{AOA}$ and $\mathrm{AOB}$ community adapted to the subsequent stress and maintained its function. This was supported by ammonia oxidizing microorganisms were very sensitive to and rapidly inhibited by heavy metals in the short term [44]whereas in the long term maintenance of ammonia oxidization-mediated ecosystem function under metal stress occured via changes in AOB and AOA community composition [45]. This was also confirmed by our results that PNR varied little while AOB and AOA community highly differed between different initial copper intensities after five years.

Take these points together, functional redundancy might explain the phenomenon of little changes in activities of microorganisms despite evidently change in community structure. In fact, functional redundancy in microbial communities has been suggested to be high with many species performing the same functions [46-48]. It was also considered important in maintaining microbial stability [49]. Recent work suggests that microbial communities becoming high functional redundancy were owing to niches being occupied stochastically, so that functional composition is more meaningful than community composition [50]. Microbial communities should perhaps be evaluated not on species composition, but focus on the core functional pathways [51] and interactions. Function is not phylogenetically conserved which means one core function is being performed by various microorganisms, thus, investigation on response to disturbance based on phylogenetic structure may be misleading. This suggests that a system approach is needed, integrating community composition, process rates, temporal fluctuations, interactions and feedbacks [45].

In conclusion, our results demonstrated that exposure to copper stress could increase the resistance of soil microorganisms to the subsequent copper stress. In addition, it is important to understand how repeated stresses influence microbial community, which could predict the changes of ecological functions to environmental fluctuations. Previous studies have shown that microbial communities are often influenced by stresses [43, 52-53]. Nevertheless, these responses are determined by the characteristics of stresses, such as type, intensity and frequency. So far, only Berga [54] designed two experiments including disturbance intensity and disturbance frequency to explore the divergences of responses. Therefore, in the future, it is far reaching to launch more comprehensive studies to 
investigate how on Earth stresses of various characteristics influence microbial community composition and function.

\section{Acknowledgements}

This study was funded by Natural Sciences Foundation of China (41025004 \& 41201523) and the Ministry of Environmental Protection (201009032-03).

\section{References}

1. Rykiel EJ (1985) Towards a definition of ecological disturbance. Aust J Ecol 10: 361-365.

2. Luo WQ, Chen JH, Yuan JG (1999) The mechanism of copper tolerance. Progress in Biotechnol 19:22-27(in Chinese)

3. Bolan NS, Adriano DC, Mahimairaja S (2004) Distribution and bioavailability of trace elements in livestock and poultry manure by-products. Environ Sci Technol 34: 291-338

4. Komarek M, Cadkova E, Chrastny V, Bordas F, Bollinger JC (2010) Contamination of vineyard soils with fungicides: A review of environmental and toxicological aspects. Environ Int 36: $138-151$.

5. Wightwick A, Mollah M, Partington D, Allinson G (2008) Copper fungicide residues in Australian vineyard soils. J Agric Food Chem 56: 2457-2464.

6. Chander K, Brookes PC (1991) Effects of heavy metals from past applications of sewage sludge on microbial biomass and organic matter accumulation in a sandy loam and silty loam U.K. soil. Soil Biol Biochem 23: 927-932.

7. Wang YP, Shi JY, Wang H, Lin Q, Chen XC, Chen YX (2007) The influence of soil heavy metals pollution on soil microbial biomass, enzyme activity, and community composition near a copper smelter. Ecotoxicol Environ Saf 67: 75-81.

8. Wrage N, Velthof GL, van Beusichem ML, Oenema O (2001) Role of nitrifier denitrification in the production of nitrous oxide. Soil Biol Biochem 33: 1723-1732.

9. Boer W De, Kowalchuk GA (2001) Nitrification in acid soils: micro-organisms and mechanisms. Soil Biol Biochem 33: 853-866

10. Könneke M, Bernhard AE, de la Torre JR, Walker CB, Waterbury JB, Stahl DA (2005)Isolation of an autotrophic ammonia-oxidizing marine archaeon. Nature 437: 543-546. 
11. Chang YJ, Hussain A, Stephen JR, Mullen MD, White DC, Peacock A (2001) Impact of herbicides on the abundance and structure of indigenous beta-subgroup ammonia-oxidizer communities in soil microcosms. Environ Toxicol Chem 20:2462-2468.

12. Oved T, Shaviv A, Goldrath T, Mandelbaum RT, Minz D (2001) Influence of effluent irrigation on community composition and function of ammonia-oxidizing bacteria in soil. Appl Environ Microbiol 67: 3426-3433

13. Ying JY, Zhang LM, He JZ (2010) Putative ammonia-oxidizing bacteria and archaea in an acidic red soil with different land utilization patterns. Environ Microbiol Rep 2: 304-312.

14. Folke C, Carpenter S, Walker B, Scheffer M, Elmqvist T, Gunderson L, Holling CS (2004) Regime Shifts, Resilience, and Biodiversity in Ecosystem Management. Annu Rev Ecol Evol Syst 35:557-581, doi:10.1146/annurev.ecolsys.35.021103.105711.

15. Pimm SL (1984) The complexity and stability of ecosystems. Nature 307: 321-326

16. Macdonald CA, Clark IM, Zhao FJ, Hirsch PR, Singh BK, McGrath SP (2011) Long-term impacts of zinc and copper enriched sewage sludge additions on bacterial, archaeal and fungal communities in arable and grassland soils. Soil Biol Biochem 43: 932-941.

17. Lejon DPH, Martins JMF, Leveque J, Spadini L, Pascault N, Landry D, Milloux MJ, Nowak V, Chaussod R, Ranjard L (2008) Copper dynamics and impact on microbial communities in soils of variable organic status. Environ Sci Technol 42: 2819-2825.

18. Philippot L, Cregut M, Cheneby D, Bressan M, Dequiet S, Martin-Laurent F, Ranjard L, Lemanceau P (2008) Effect of primary mild stresses on resilience and resistance of nitrate reducer community to a subsequent severe stress. FEMS Microbiol Lett 285: 51-57

19. Tobor-Kaplon MA, Bloem J, Romkens PFAM, De Ruiter PC (2006) Functional stability of microbial communities in contaminated soils near a zinc smelter (Budel, The Netherlands).Ecotoxicology 15: 187-197.

20. Mertens J, Springael D, De Troyer I, Cheyns K, Wattiau P, Smolders E (2006) Long-term exposure to elevated zinc concentrations induced structural changes and zinc tolerance of the nitrifying community in soil. Environ Microbiol 8: 2170-2178.

21. Kurola J, Salkinoja-Salonen M, Aarnio T, Hultman J, Romantschuk M (2005) Activity, diversity and population size of ammonia-oxidising bacteria in oil-contaminated land farming soil. FEMS Microbiol Ecol 250: 33-38 
22. He JZ, Shen JP, Zhang LM, Zhu YG, Zheng YM, Xu MG, Di HJ (2007) Quantitative analyses of the abundance and composition of ammonia-oxidizing bacteria and ammonia-oxidizing archaea of a Chinese upland red soil under long-term fertilization practices. Environ Microbiol, 9: 2364-2374.

23. Soil quality - Determination of abundance and activity of soil microflora using respiration curves. ISO, 17155:2002

24. Suzuki MT, Taylor LT, DeLong EF (2000) Quantitative analysis of small-subunit rRNA genes in mixed microbial populations via 5'-nuclease assays. Appl Environ Microbiol 66: 4605-4614.

25. Cao P, Zhang LM, Shen JP, Zheng YM, Di HJ, He JZ (2011) Distribution and diversity of archaeal communities in selected Chinese soils. FEMS Microbiol Ecol 80:146-158

26. Kemnitz D, Kolb S, Conrad R (2007) High abundance of Crenarchaeota in a temperate acidic forest soil. FEMS Microbiol Ecol 60: 442-448.

27. Francis CA, Roberts KJ, Beman JM, Santoro AE, Oakley BB (2005) Ubiquity and diversity of ammonia-oxidizing archaea in water columns and sediments of the ocean. Proc Natl Acad Sci USA, 102:14683-14688

28. Zhang LM, Hu HW, Shen JP, He JZ (2012) Ammonia-oxidizing archaea have more important role than ammonia-oxidizing bacteria in ammonia oxidation of strongly acidic soils. ISME J 6: $1032-1045$.

29. Rotthauwe JH, Witzel KP, Liesack W (1997) The ammonia monooxygenase structural gene amoA as a functional marker: molecular fine-scale analysis of natural ammonia-oxidizing populations. Appl Environ Microbiol 63: 4704-4712.

30. Yuan H, Ge T, Wu X, Liu S, Tong C, Qin H, Wu M, Wei W, Wu J (2012) Long-term field fertilization alters the diversity of autotrophic bacteria based on the ribulose-1,5-biphosphate carboxylase/oxygenase (RubisCO) large-subunit genes in paddy soil. Appl Microbiol Biol 95: 1061-1071.

31. Tamura K, Dudley J, Nei M, Kumar S (2007) MEGA4: Molecular Evolutionary Genetics Analysis (MEGA) software version 4.0.Mol Biol Evol 24: 1596-1599.

32. Caporaso JG, Kuczynski J, Stombaugh J et al (2010) QIIME allows analysis of high-throughput community sequencing data. Nat Methods 7:335-336

33. Shade A, Read JS, Welkie DG, Kratz TK, Wu CH, McMahon KD (2011) Resistance, resilience and recovery: aquatic bacterial dynamics after water column disturbance. Environ Microbiol 13: 
2752-2767

34. Jiménez MA, Jaksic FM, Armesto JJ, Gaxiola A, Meserve PL, Kelt DA, Gutiérrez JR (2011) Extreme climatic events change the dynamics and invisibility of semi-arid annual plant communities. Ecol Lett 14:1227-1235

35. Gołębiewski M, Deja-Sikora E, Cichosz M, Tretyn A, Wróbel B (2014) 16S rDNA pyrosequencing analysis of bacterial community in heavy metals polluted soils. Microb Ecol. doi:10.1007/s00248-013-0344-7

36. Singh BK, Quince C, Macdonald CA, Khachane A, Thomas N, Abu Al-Soud W, Sørensen SJ, He ZL, White D, Sinclair A, Crooks B, Zhou JZ, Campbell CD (2014) Loss of microbial diversity in soils is coincident with reductions in some specialized functions. Environ Microbiol. doi:10.1111/1462-2920.12353

37. Allison SD, Martiny JBH (2008) Resistance, resilience, and redundancy in microbial communities. Proc. Natl. Acad. Sci. USA 105: 11512-11519

38. Kristian KB, Rasmus JNF, Peter EH, Ole N (2010) Development of pollution-induced community tolerance is linked to structural and functional resilience of a soil bacterial community following a five-year field exposure to copper. Soil Biol Biochem 42: 748-757

39. Demoling AL, Baath E (2008) Use of pollution-induced community tolerance (PICT) of the bacterial community to detect phenol toxicity in soil. Environ Toxicol Chem 27: 344-350

40. Martinez RJ, Wang Y, Raimondo MA, Coombs JM, Barkay T, Sobecky PA (2006) Horizontal gene transfer of PIB-type ATPases among bacteria isolated from radionuclide- and metal-contaminated subsurface soils. Appl Environ Microbiol 72: 3111-3118.

41. Thomas CM, Nielsen KM (2005) Mechanisms of, and barriers to, horizontal gene transfer between bacteria. Nat Rev Microbiol 3: 711-721.

42. Ramos JL, Duque E, Gallegos MT, Godoy P, Ramos-Gonzalez MI, Rojas A, Teran W, Segura A (2002) Mechanisms of solvent tolerance in gram-negative bacteria. Annu. Rev of Microbiol 56: $743-768$

43. Hemme CL, Deng Y, Gentry TJ et al (2010) Metagenomic insights into evolution of a heavy metal contaminated groundwater microbial community. ISME J 4:660-672

44. Liu YR, Zheng YM, Shen JP, Zhang LM, He JZ (2010) Effects of mercury on the activity and community composition of soil ammonia oxidizers. Environ Sci Pollut Res 17:1237-1244. 
45. Bissett A, Brown MV, Siciliano SD, Thrall PH (2013) Microbial community response to anthropogenically induced environmental change: towards a systems approach. Ecol Lett 16:128-139

46. Wohl DL, Arora S, Gladstone JR (2004) Functional redundancy supports biodiversity and ecosystem function in a closed and constant environment. Ecology 85: 1534-1540.

47. Langenheder S, Lindström ES, Tranvik LJ (2005) Weak coupling between community composition and functioning of aquatic bacteria. Limnol Oceanogr 50: 957-967.

48. Comte J, del Giorgio PA (2010) Linking the patterns of change in composition and function in bacterioplankton successions along environmental gradients. Ecology 91:1466-1476.

49. Mertens J, Broos K, Wakelin SA, Kowalchuk GA, Springael D, Smolders E (2009) Bacteria, not archaea, restore nitrification in a zinc contaminated soil. ISME J 3: 916-923

50. Barberan A, Bates ST, Casomayor EO, Fierer N (2011) Using network analysis to explore co-occurrence patterns in soil microbial communities. ISME J 6:343-351

51. Burke C, Steinberg P, Rusch D, Kjelleberg S, Thomas T (2011) Bacterial community assembly based on functional genes rather than species. Proc Natl Sci USA 108: 14288-14293.

52. Margesin R, Plaza GA, Kasenbacher S (2011) Characterization of bacterial communities at heavy metal contaminated sites. Chemosphere 82: 1583-1588

53. Chaer G, Fernandes M, Myrold D, Bottomley P (2009) Comparative resistance and resilience of soil microbial communities and enzyme activities in adjacent native forest and agricultural soils. Microb Ecol 58: 414-424.

54. Berga M, Szekely AJ, Langenheder S (2012) Effects of disturbance intensity and frequency on bacterial community composition and function. Plos One 7: e36959 
Table 1 Soil characteristics of the examined samples from field plots

\begin{tabular}{|c|c|c|c|c|c|c|c|c|}
\hline Treatment & $p H$ & $\begin{array}{l}\mathrm{H}_{2} \mathrm{O} \\
(\%)\end{array}$ & $\begin{array}{c}S O C \\
\left(g k^{-1}\right)\end{array}$ & $\begin{array}{c}D O C \\
\left(m g k g^{-1}\right)\end{array}$ & $\begin{array}{c}\text { Biomass C } \\
\left(m g \mathrm{~kg}^{-1}\right)\end{array}$ & $\begin{array}{l}\text { Cu added } \\
\left(m g \mathrm{~kg}^{-1}\right)\end{array}$ & $\begin{array}{l}\text { Cu total } \\
\left(m g \mathrm{~kg}^{-1}\right)\end{array}$ & $\begin{array}{c}\text { Exchangeable } \mathrm{Cu} \\
\left(m g \mathrm{~kg}^{-1}\right)\end{array}$ \\
\hline$\overline{\mathrm{Cu} 0}$ & $\begin{array}{l}7.8 \\
\end{array}$ & 14.1 & 13.4 & 122.5 & 93.3 & 0 & 8.2 & 0.5 \\
\hline Cu50 & 7.7 & 14.2 & 11.3 & 237.5 & 15.1 & 50 & 25.3 & 3.6 \\
\hline Cu100 & 8.1 & 13.6 & 12.3 & 137.9 & 43.1 & 100 & 47.3 & 12.9 \\
\hline $\mathrm{Cu} 200$ & 8.0 & 15.8 & 11.5 & 106.5 & 24.8 & 200 & 280.4 & 38.7 \\
\hline $\mathrm{Cu} 400$ & 8.0 & 15.8 & 12.8 & 83.0 & 22.0 & 400 & 444.2 & 134.6 \\
\hline $\mathrm{Cu} 800$ & 7.9 & 15.5 & 12.3 & 47.3 & 60.6 & 800 & 865.0 & 406.0 \\
\hline $\mathrm{Cu} 1600$ & 7.8 & 16.7 & 11.8 & 40.5 & 23.4 & 1600 & 1374.7 & 951.8 \\
\hline Cu3200 & 7.7 & 16.8 & 12.0 & 53.7 & 12.7 & 3200 & 3341.0 & 2605.3 \\
\hline
\end{tabular}

SOC, soil organic carbon; DOC, dissolved organic carbon extracted by $0.5 \mathrm{~mol} \mathrm{l}^{-1} \mathrm{~K}_{2} \mathrm{SO}_{4}$; Exchangeable copper, extracted by $0.11 \mathrm{~mol} \mathrm{l}^{-1} \mathrm{CH}_{3} \mathrm{COOH}$ 


\section{Figure legends}

Figure 1 Changes in potential nitrification rates (PNR) (a) and substrate induced respiration (SIR) in soils across eight treatments included $\mathrm{Cu} 0, \mathrm{Cu} 50, \mathrm{Cu} 100, \mathrm{Cu} 200, \mathrm{Cu} 400, \mathrm{Cu} 800, \mathrm{Cu} 1600$ and $\mathrm{Cu} 3200$. Error bars indicate standard deviation.

Figure 2 Abundance of microorganisms in the eight $\mathrm{Cu}$-added treatments: (a) Bacterial 16S rRNA gene copy numbers, (b) Archaeal 16S rRNA gene copy numbers, (c) AOB amoA gene copy numbers, (d) AOA amoA gene copy numbers. Error bars indicate standard deviation.

Figure 3 The percentages of TRFs in the eight treatments based on bacterial (a), archaeal (c), AOB (e) and AOA (g) communities, respectively. The PCoA based on Bray-Curtis dissimilarities of bacterial (b), $\operatorname{archaeal}(\mathrm{d})$, AOB (f) and AOA (h) communities, respectively. Error bars indicate standard deviation.

Figure 4 (a) Potential nitrification rates in four treatments including $\mathrm{Cu} 0-\mathrm{C}, \mathrm{Cu} 0-\mathrm{A}, \mathrm{Cu} 3200-\mathrm{C}$ and Cu3200-A on days 0, 3, 7, 21, 42 and 90. (b) Substrate induced respiration (SIR) in four treatments including $\mathrm{Cu} 0-\mathrm{C}, \mathrm{Cu} 0-\mathrm{A}, \mathrm{Cu} 3200-\mathrm{C}$ and $\mathrm{Cu} 3200-\mathrm{A}$ on days 0, 3, 7, 21, 42 and 90. Error bars indicate standard deviation.

Figure 5 Abundance of microorganisms in four treatments including $\mathrm{Cu} 0-\mathrm{C}, \mathrm{Cu} 0-\mathrm{A}, \mathrm{Cu} 3200-\mathrm{C}$ and Cu3200-A on days 0, 3, 7, 21, 42 and 90: (a) Bacterial 16S rRNA gene copy numbers, (b) Archaeal 16S rRNA gene copy numbers, (c) AOB amoA gene copy numbers, (d) AOA amoA gene copy numbers. Error bars indicate standard deviation.

Figure 6 The percentages of TRFs in four treatments including $\mathrm{Cu} 0-\mathrm{C}, \mathrm{Cu} 0-\mathrm{A}, \mathrm{Cu} 3200-\mathrm{C}$ and Cu3200-A on days $0,3,7,21,42$ and 90 based on bacterial (a), archaeal (c), AOB (e) and AOA (g) communities. The Bray-Curtis dissimilarities of bacterial (b), archaeal (d), AOB (f) and AOA (h) communities between $\mathrm{Cu} 0-\mathrm{A}$ and $\mathrm{Cu} 0-\mathrm{C}$ on day 0 as well as $\mathrm{Cu} 3200-\mathrm{A}$ and $\mathrm{Cu} 3200-\mathrm{C}$ on day 0. Light grey columns were added to highlight the Bray-Curtis dissimilarities on days 0, 3 and 90. Error bars indicate standard deviation. 
Figure 1
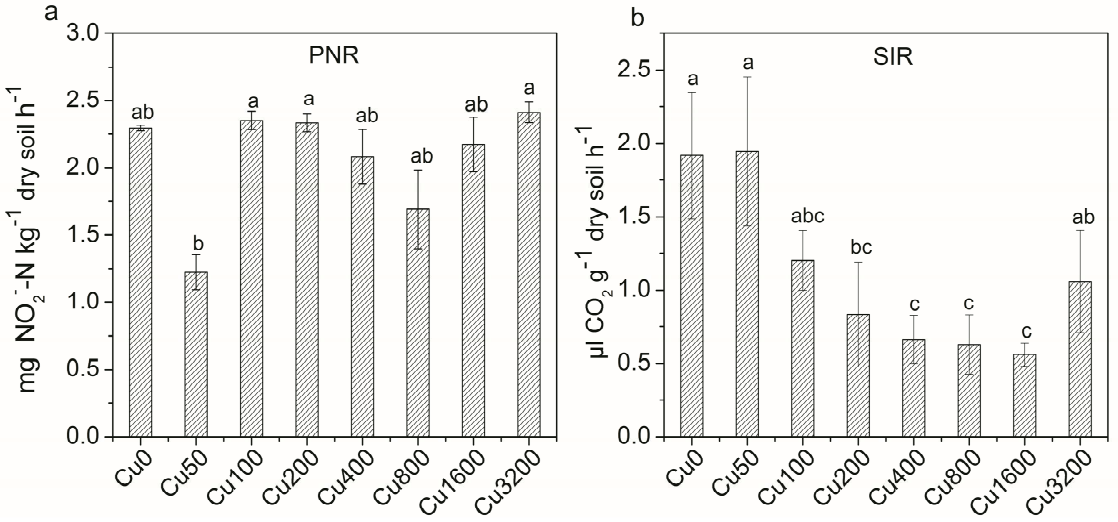
Figure 2
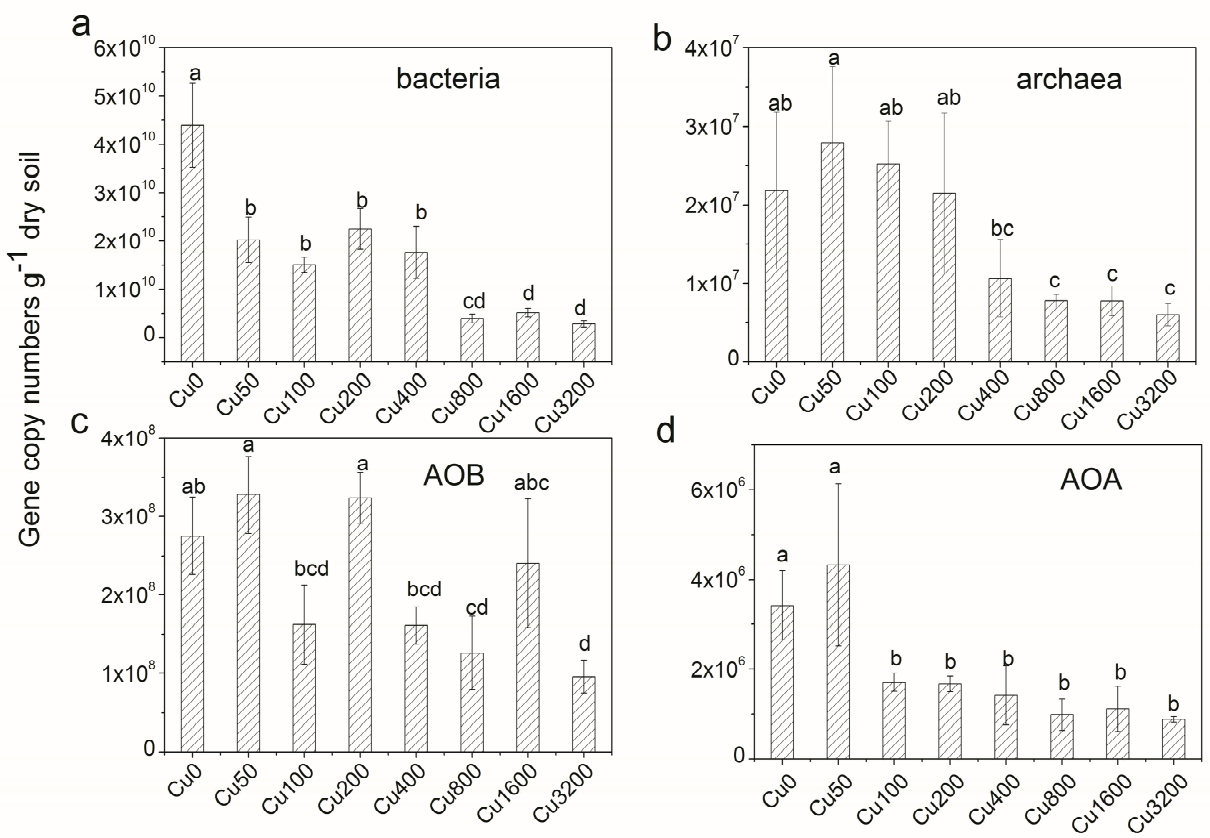
Figure 3
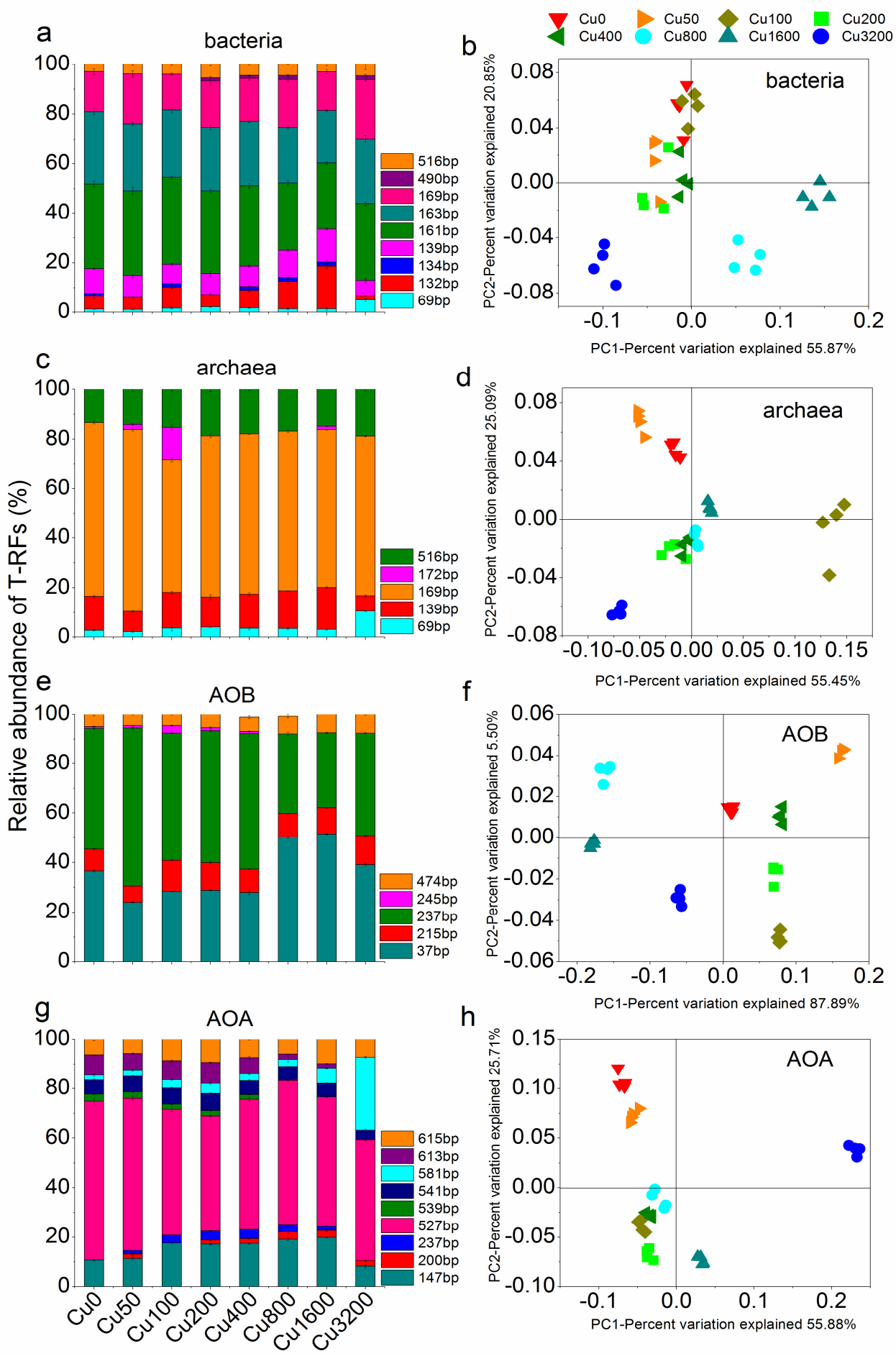
Figure 4
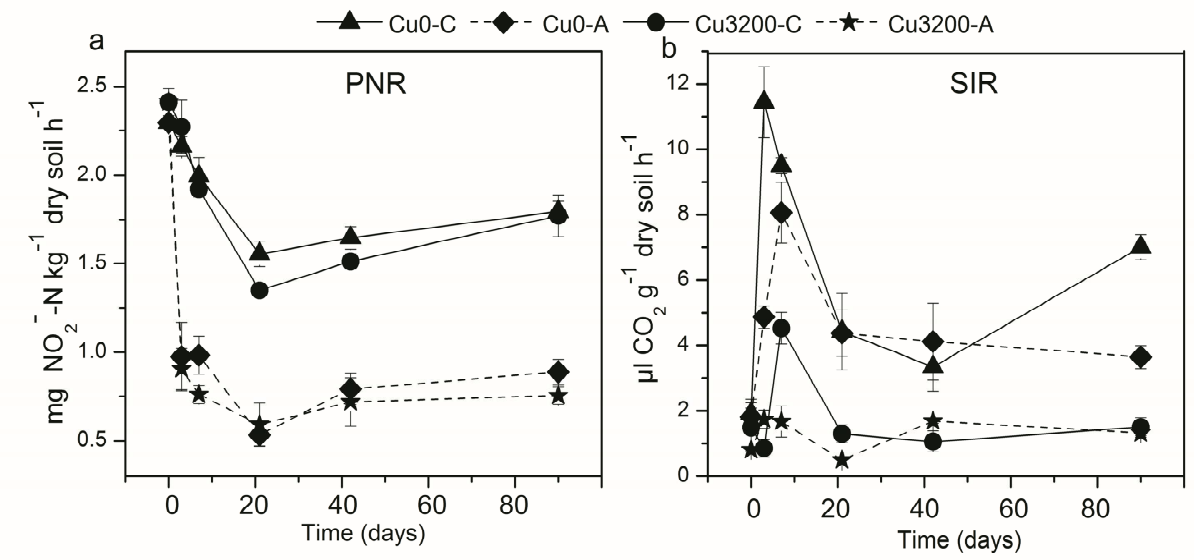
Figure 5
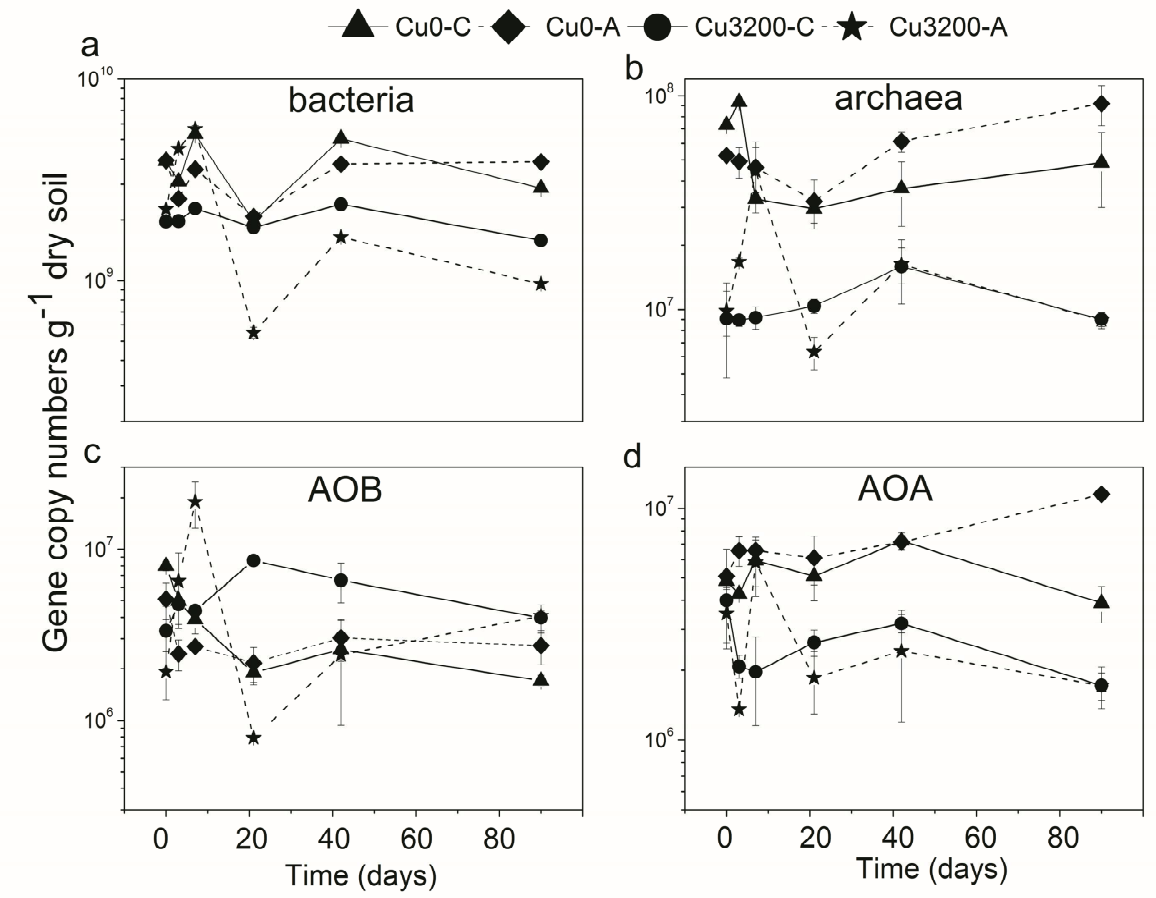
Figure 6

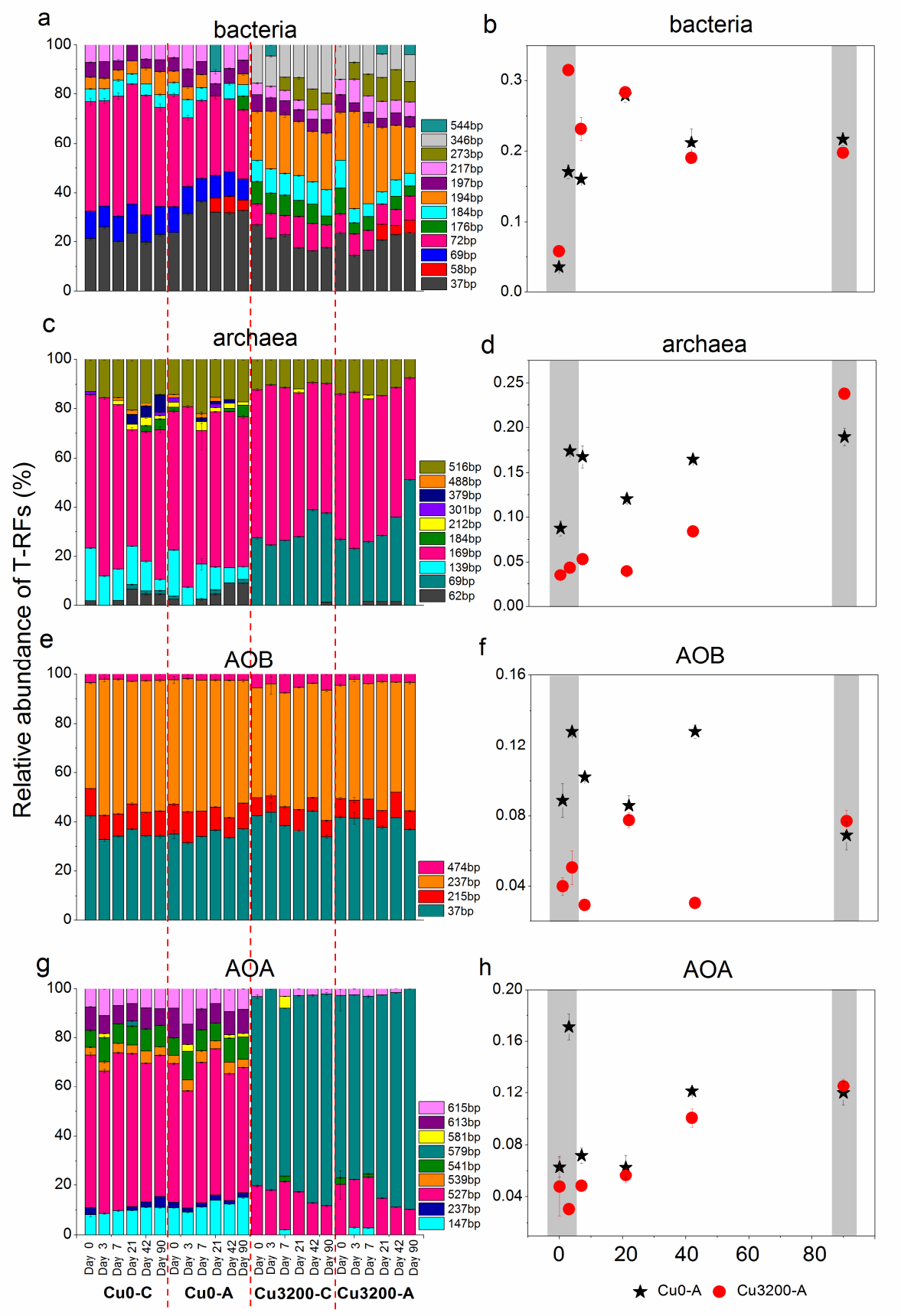




\section{University Library}

\section{- M M N E R VA A gateway to Melbourne's research publications}

Minerva Access is the Institutional Repository of The University of Melbourne

Author/s:

Li, J;Zheng, Y-M;Liu, Y-R;Ma, Y-B;Hu, H-W;He, JZ

Title:

Initial Copper Stress Strengthens the Resistance of Soil Microorganisms to a Subsequent Copper Stress

Date:

2014-05-01

Citation:

Li, J., Zheng, Y. -M., Liu, Y. -R., Ma, Y. -B., Hu, H. -W. \& He, J. Z. (2014). Initial Copper Stress Strengthens the Resistance of Soil Microorganisms to a Subsequent Copper Stress. MICROBIAL ECOLOGY, 67 (4), pp.931-941. https://doi.org/10.1007/s00248-014-0391-8.

Persistent Link:

http://hdl.handle.net/11343/282959 